\title{
Effects of the selective GPER1 agonist G1 on bone growth
}

\author{
Maryam Iravani ${ }^{1}$, Marie K Lagerquist ${ }^{2}$, Elham Karimian ${ }^{1}$, Andrei S Chagin ${ }^{3,4}$, Claes Ohlsson ${ }^{2}$ and Lars Sävendahl ${ }^{1}$ \\ 1Department of Women's and Children's Health, Karolinska Institutet and Pediatric Endocrinology Unit, Karolinska University Hospital, Solna, Sweden \\ ${ }^{2}$ Center of Bone and Arthritis Research, Institute of Medicine, Sahlgrenska Academy at University of Gothenburg, Gothenburg, Sweden \\ ${ }^{3}$ Department of Physiology and Pharmacology, Karolinska Institutet, Solna, Sweden \\ ${ }^{4}$ Institute for Regenerative Medicine, Sechenov University, Moscow, Russian Federation \\ Correspondence should be addressed to M Iravani: maryam.iravani@ki.se
}

\begin{abstract}
Estrogens may affect bone growth locally or systemically via the known estrogen receptors ESR1, ESR2 and G protein-coupled estrogen receptor 1 (GPER1). Mouse and human growth plate chondrocytes have been demonstrated to express GPER1 and ablation of this receptor increased bone length in mice. Therefore, GPER1 is an attractive target for therapeutic modulation of bone growth, which has never been explored. To investigate the effects of activated GPER1 on the growth plate, we locally exposed mouse metatarsal bones to different concentrations of the selective GPER1 agonist G1 for 14 days ex vivo. The results showed that none of the concentrations of $\mathrm{G} 1$ had any direct effect on metatarsal bone growth when compared to control. To evaluate if GPER1 stimulation may systemically modulate bone growth, ovariectomized C57BL/6 mice were treated with G1 or $\beta$-estradiol (E2). Similarly, G1 did not influence tibia and femur growth in treated mice. As expected, E2 treatment suppressed bone growth in vivo. We conclude that ligand stimulation of GPER1 does not influence bone growth in mice.
\end{abstract}
Key Words
- growth plate
- growth
- chondrocytes
- estrogen
- GPER1

- G1

- bone

\section{Introduction}

Estrogen signaling is mediated via two nuclear and one membranous estrogen receptors (ER). Nuclear receptors ER alpha and beta (ESR1 and ESR2) are activated by the binding of specific ligands, followed by the activation of gene transcription (1). In contrast to the classical nuclear receptor signaling, membranous ERs exert their rapid effects via posttranslational modification and recruitment of transcription factors to their DNA-binding sites (2). In contrast to the nuclear ERs, activation of GPER1, a transmembrane ER, leads to rapid changes in the concentrations of messenger molecules and regulation of kinase pathways.

Several studies have found that GPER1 is widely expressed in human tissues, such as, lungs, heart, and the immune system, including myeloid and lymphoid immune cells $(3,4)$. Moreover, important functional roles of GPER1 in the reproductive, immune, cardiovascular, endocrine and nervous systems have previously been reported $(5,6)$. Furthermore, expression of GPER1 has also been reported in human stem cells (7). In addition to the physiological effects, GPER1 might be involved in various estradiol (E2)-dependent diseases, such as atherosclerosis, osteoporosis, autoimmunity and tumors of the reproductive system (4).

With regard to connective tissues, the expression of ESR1, ESR2 and GPER1 has previously been demonstrated in human bone and growth plate cartilage $(8,9)$ as well as in rat spinal and tibial growth plate chondrocytes (10). Moreover, cytoplasmic expression of GPER1 has been detected in human osteoblasts, osteocytes and osteoclasts (9). Expression of GPER1 has also been found in the cellular compartments outside the nuclei and treatment with E2 had a protective effect against mitophagy via the GPER1 signaling pathway in mouse ATDC5 chondrocytes
This work is licensed under a Creative Commons Attribution-NonCommercial-NoDerivatives 4.0 elnternationab ticense.ifica.com at 04/26/2023 01:56:31PM 
(11). Earlier in vitro studies have shown that E2 binds to GPER1 (12) and stimulates growth of ESR1-negative breast and endometrial tumor cells $(13,14)$. Furthermore, a high dose of E2 inhibited longitudinal bone growth in WT but not in Gper1-l- mice, suggesting a physiological function of GPER1 in E2-signaling in the growth plate (15). Moreover, male Gper1 ${ }^{-/-}$mice were reported to have increased bone mineralization and proliferation in the growth plate (16). Based on these data, we hypothesized that modulation of GPER1 activity may be an attractive therapeutic strategy in children with abnormal growth including extreme short and tall stature. Since E2, the main natural GPER1 agonist, can influence growth plate cartilage and bone growth via both local and systemic routes (1), we designed two distinct experiments to test whether a selective GPER1 agonist G1 may affect bone growth. To study any local effects, mouse metatarsal bones were treated with G1 ex vivo. To explore any systemic bone growth effects of the GPER1 agonist, ovariectomized (OVX) female mice were challenged with G1.

\section{Materials and methods}

\section{Reagents}

G protein-coupled estrogen receptor 1 (GPER1) selective agonist G1 was obtained from Merck Chemicals. Bovine serum albumin (BSA), $\beta$-glycerophosphate disodium salt hydrate and $17 \beta$-estradiol-3-benzoate (E2) were purchased from Sigma-Aldrich. Phosphate buffer saline (PBS), DMEM/F12 phenol red-free medium and gentamycin were bought from Invitrogen. L-Ascorbic acid A4403 and $\beta$-glycerophosphate disodium salt hydrate G 9422 were purchased from Sigma.

Primary rabbit anti-PCNA antibody (ab18197) was provided by Abcam. Normal donkey serum and secondary CY3-conjugated AffiniPureF(ab) Fragment Donkey Anti-Rabbit IgG antibody were purchased from Jackson ImmunoResearch Laboratories. Fluorescence mounting medium was obtained from Dako. 4',6-Diamidino-2phenylindole dihydrochloride (DAPI) was purchased from Sigma-Aldrich.

\section{Animals}

Four-day-old mouse pups C57BL/6 were purchased from Charles River Laboratories. Pups were killed $1 \mathrm{~h}$ after arrival to the animal facility at Karolinska University Hospital in Solna, Sweden. For ex vivo organ cultures, the three middle metatarsal bones were dissected out from each hind paw and cultured as described below ( $n=9 /$ group). The study was approved by the ethical committee for animal experiments at the Karolinska Institutet, Solna (permit no. N 254/10). All applicable international, national, and/or institutional guidelines for the care and use of animals were followed.

For in vivo studies, 12-week-old female C57BL/6 mice ( $n=9-10 /$ group) were purchased from Charles River Laboratories. Animals were housed in the animal facility at the University of Gothenburg, Sweden and kept in 12-h day and night condition with standard chow and tap water ad libitum. The study was approved by the ethical committee for animal experiments at the University of Gothenburg (permit no. 205-2007).

\section{Organ culture}

After dissection, metatarsal bones were transferred to 24-well plates and cultured in $1 \mathrm{~mL}$ of phenol red-free and estrogen-free DMEM/F12 medium supplemented with $0.1 \% \mathrm{BSA}, 1 \mathrm{mM} \beta$-glycerophosphate, $0.05 \mathrm{mg} / \mathrm{mL}$ ascorbic acid and $20 \mu \mathrm{g} / \mathrm{mL}$ gentamicin added at $37^{\circ} \mathrm{C}$ under a humidified atmosphere containing $5 \% \mathrm{CO}_{2}$ according to the protocol established by us previously (17). The bones were co-cultured with either vehicle (DMSO) or G1 $(1,10$, 100 and $300 \mathrm{nM}$ ) dissolved in DMSO. The medium was changed every other day. Digital pictures were captured on day $0,2,5,7,9,12$ and 14 using a Hamamatsu C4742-95 digital camera attached to a Nikon SMZ-U microscope. The length of each metatarsal bone was measured blindly using the ImageJ software (NIH). The increase in bone length was expressed as a delta of the length at the day of dissection (day $0=$ baseline).

\section{Ovariectomy and in vivo treatment}

Mice were randomized into four different groups. Three groups were OVX and one group was sham-operated. Both ovariectomy and sham operations were performed at 12 weeks of age under intraperitoneal anesthesia with ketamine (Ketalar; Pfizer) and medetomidine (Domitor; Orion Pharma, Espoo, Finland). Carprofen (Orion Pharma) was used postoperatively for pain relief. A midline incision was followed by flank incisions of the peritoneum, and the ovaries were removed with sterile scissors. The skin incisions were closed with metal clips. The sham-operated mice were treated in the same way, except that the ovaries were not removed. Sham-operated mice were subcutaneously (s.c.) injected with $100 \mu \mathrm{L}$ of

This work is licensed under a Creative Commons Attribution-NonCommercial-NoDerivatives 4.0 Internationab ticense.ifica.com at 04/26/2023 01:56:31PM 
vehicle (10\% ethanol and 90\% Miglyol 812; Omya Peralta, Hamburg, Germany) ( $n=10)$. OVX mice were treated s.c. with $100 \mu \mathrm{L}$ of $\mathrm{E} 2(1 \mu \mathrm{g} / \mathrm{mouse} ; 0.04 \mathrm{mg} / \mathrm{kg} / \mathrm{day})(n=9)$, G1 $(5 \mu \mathrm{g} / \mathrm{mouse} ; 0.2 \mathrm{mg} / \mathrm{kg} /$ day) $(n=9)$ or vehicle $(n=10)$. Biological activity of G1 at the chosen well-established dose has previously been demonstrated in vivo $(18,19)$. All groups received treatments 5 days per week for 4 weeks. The data from E2 and control groups have been previously published by our group (20).

\section{Quantitative histology of tibia growth plates from in vivo-treated mice}

After killing, bones were dissected out and the length of the tibiae and femora was measured with a pocket Vernier caliper (Helios-Preisser, Gammertingen, Germany). The tibiae were fixed in 4\% phosphate-buffered formalin for $24 \mathrm{~h}$, decalcified in 10\% EDTA for 2 weeks and stored in $70 \%$ ethanol. For histological analysis, tibiae were embedded in paraffin and $5 \mu \mathrm{m}$ thick sections were prepared from the paraffin blocks and stained with Alcian blue/van Gieson. The quantitative analysis was performed by measuring two-third of the growth plate sections at $10 \times$ magnification. Images were captured by a Nikon Eclipse E800 light microscope (Nikon) connected to the digital camera. The heights of the tibia growth plate, proliferative and hypertrophic zones were calculated as an average of 20 measurements per growth plate. Hypertrophic chondrocytes were defined as cells with a height larger than $7 \mu \mathrm{m}$. All measurements were made in a blind manner using the Image Pro Plus, version 6.3 software.

\section{Immunofluorescence for the detection of PCNA expression}

For immunofluorescence, the tibia growth plate sections were deparaffinized for $40 \mathrm{~min}$ at $60^{\circ} \mathrm{C}$, rehydrated in xylene, 100\% ethanol, 95\% ethanol and 75\% ethanol, for $5 \mathrm{~min}$ in each solution and finally washed with water. Sodium citrate buffer ( $10 \mathrm{mM}, \mathrm{pH} 6.0)$ was used for antigen retrieval for $15 \mathrm{~min}$ at $95^{\circ} \mathrm{C}$. Following the retrieval, the slides were incubated with 1.5\% donkey serum in PBS for $1 \mathrm{~h}$ at room temperature (RT), with primary rabbit antiPCNA antibody (1:250 dilution) overnight at $4^{\circ} \mathrm{C}$ and with secondary donkey anti-rabbit antibody (1:250 dilution) for $1 \mathrm{~h}$ at RT. Nuclear staining with DAPI was performed for 15 min at RT. After the staining, the slides were mounted with Dako Fluorescence Mounting Medium.

\section{TUNEL assay (apoptosis detection)}

The TUNEL assay was performed on tibia growth plate sections according to the manufacturer's instructions. Briefly, apoptotic chondrocytes were identified by TUNEL immunohistochemistry applying the TdT-FragEL DNA fragmentation kit (Oncogene Research, Boston, MA, USA) according to the manufacturer's protocol. Alexa-546 (red florescence) (Invitrogen)-positive cells represented apoptotic chondrocytes.

\section{Statistical analysis}

All the data are presented as means \pm s.E.M., and the differences were calculated by one-way ANOVA using the SPSS software by multiple comparisons vs control group (Holm-Sidak method). ${ }^{* * *} P<0.001,{ }^{* *} P<0.01$ were considered as statistically significant.

\section{Results}

\section{Effect of G1 treatment on mouse metatarsal bone growth}

Four-day-old mouse metatarsal bones were cultured with either vehicle or the GPER1 agonist G1 at concentration $1,10,100$, or $300 \mathrm{nM}$ for 14 days. Measurements of bone lengths over the 14-day period of culture showed that none of the tested G1 concentrations had any effect on metatarsal bone growth (Fig. 1A, B, C and D).

\section{Effects of E2 and G1 on tibia and femur growth in vivo}

The effects of vehicle, E2 and G1 on tibia and femur lengths were analyzed in OVX mice. As expected, E2 inhibited both tibia and femur growth in OVX mice compared to the vehicle treated OVX group $(P<0.01$, Fig. $2 \mathrm{~A}$ and $\mathrm{B})$, whereas ovariectomy promoted bone growth in vehicle compared to sham-operated mice $(P<0.01$, Fig. $2 \mathrm{~A}$ and $\mathrm{B})$. In contrast, G1 treatment did not affect tibia and femur lengths in OVX mice compared to vehicle-treated OVX mice (Fig. 2A and B).

\section{Effects of in vivo exposure to E2 and G1 on tibia growth plate morphology}

To analyze the effects of E2 and G1 on tibia growth plate morphology, OVX mice were treated with

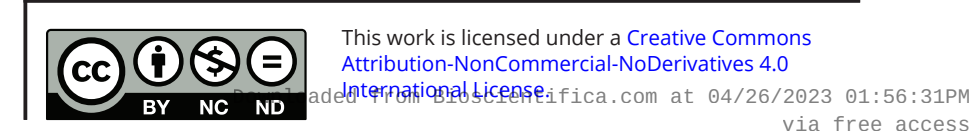


A

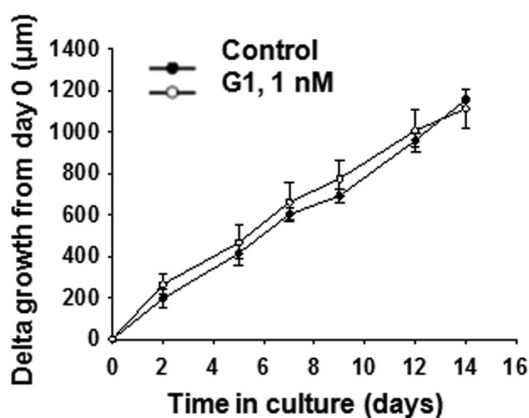

C

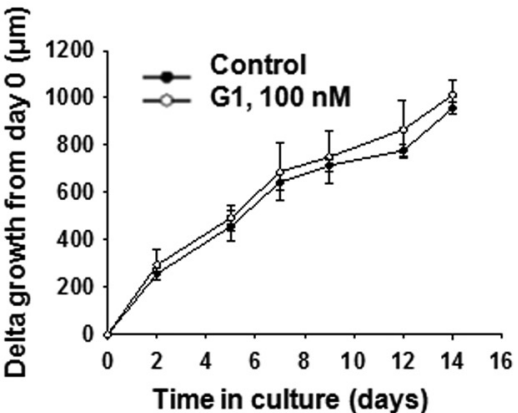

B

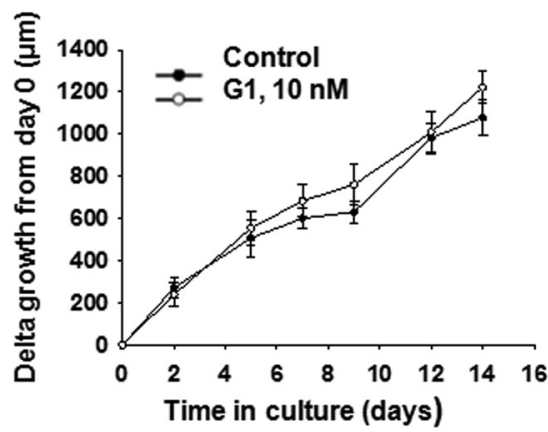

D

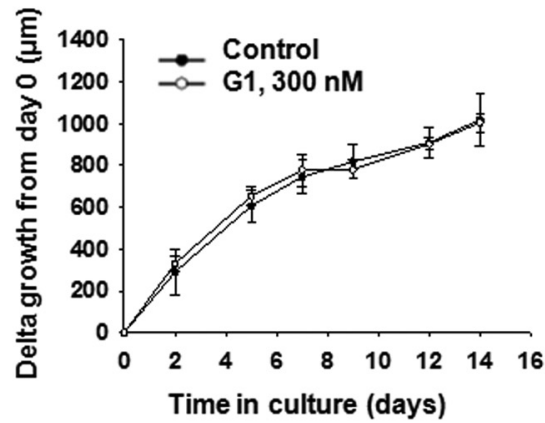

\section{Figure 1}

Effects on bone growth of the GPER1 agonist G1 in ex vivo cultured mouse metatarsal bones. The metatarsal bones were treated with $1 \mathrm{nM}(\mathrm{A})$, $10 \mathrm{nM}(\mathrm{B}), 100 \mathrm{nM}(\mathrm{C})$ or $300 \mathrm{nM}(\mathrm{D})$ of G1 or vehicle. No significant effects of $\mathrm{G} 1$ were seen at any of the concentrations $(n=9)$. All the data are presented as means \pm S.E.M., and the differences were calculated by one-way ANOVA.
E2, G1, or vehicle. As expected, histological analyses showed that the growth plate was narrower in shamoperated mice compared to vehicle-treated OVX mice $(P<0.01$, Figs $3 \mathrm{~A}, \mathrm{~B}$ and $4 \mathrm{~A})$. Treatment of OVX mice with E2 decreased growth plate height to a similar size as seen in sham-operated controls (Figs 3A, C and 4A). In contrast to E2, G1 treatment did not affect growth plate height compared to vehicle-treated OVX mice (Figs 3B, $\mathrm{D}$ and $4 \mathrm{~A})$.

Morphometric analyses showed that heights of both proliferative and hypertrophic zones were decreased in E2-treated OVX mice compared to the vehicle group $(P<0.001$, Fig. 4B and $\mathrm{C})$. In contrast, G1 treatment did not affect proliferative and hypertrophic zone heights compared to the vehicle group (Fig. 4B and C). As expected, proliferative and hypertrophic zone heights were decreased in sham-operated mice compared to vehicle-treated OVX animals ( $P<0.001$, Fig. $4 \mathrm{~B}$ and $\mathrm{C})$.

\section{Effects of in vivo treatment with E2 and G1 on chondrocyte proliferation and apoptosis}

The histological analysis of PCNA staining of tibia growth plate cartilage showed decreased proliferation in E2-treated OVX mice compared to the vehicle group. Furthermore, proliferation was also suppressed in sham-operated mice compared to the OVX vehicle group $(P<0.001$, Fig. 5A). In contrast, G1 treatment did not affect chondrocyte proliferation compared to the vehicle group (Fig. 5A). Effects of E2 and G1 on chondrocyte apoptosis were studied by TUNEL assay. No significant differences in apoptosis level were observed between the treatment groups (Fig. 5B).
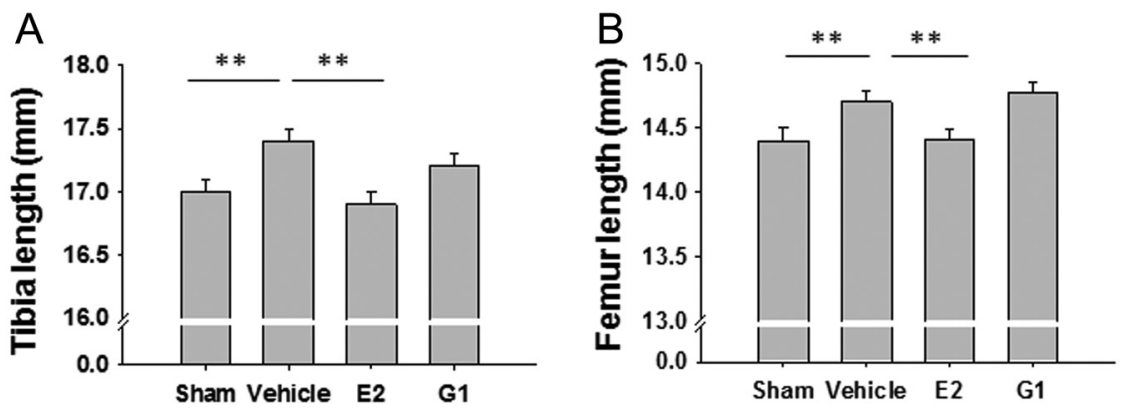

\section{Figure 2}

Effects of E2 and G1 on tibia and femur lengths. The study groups included ovariectomized mice treated with E2 $(0.04 \mathrm{mg} / \mathrm{kg} / \mathrm{day}), \mathrm{G} 1(0.2 \mathrm{mg} / \mathrm{kg} /$ day) or vehicle alone and sham-operated mice. Vehicle vs E2, vehicle vs sham, $* * P<0.01$. Tibia length (A) and femur length (B) $(n=9-10)$. All the data are presented as means \pm S.E.M., and the differences were calculated by one-way ANOVA. 

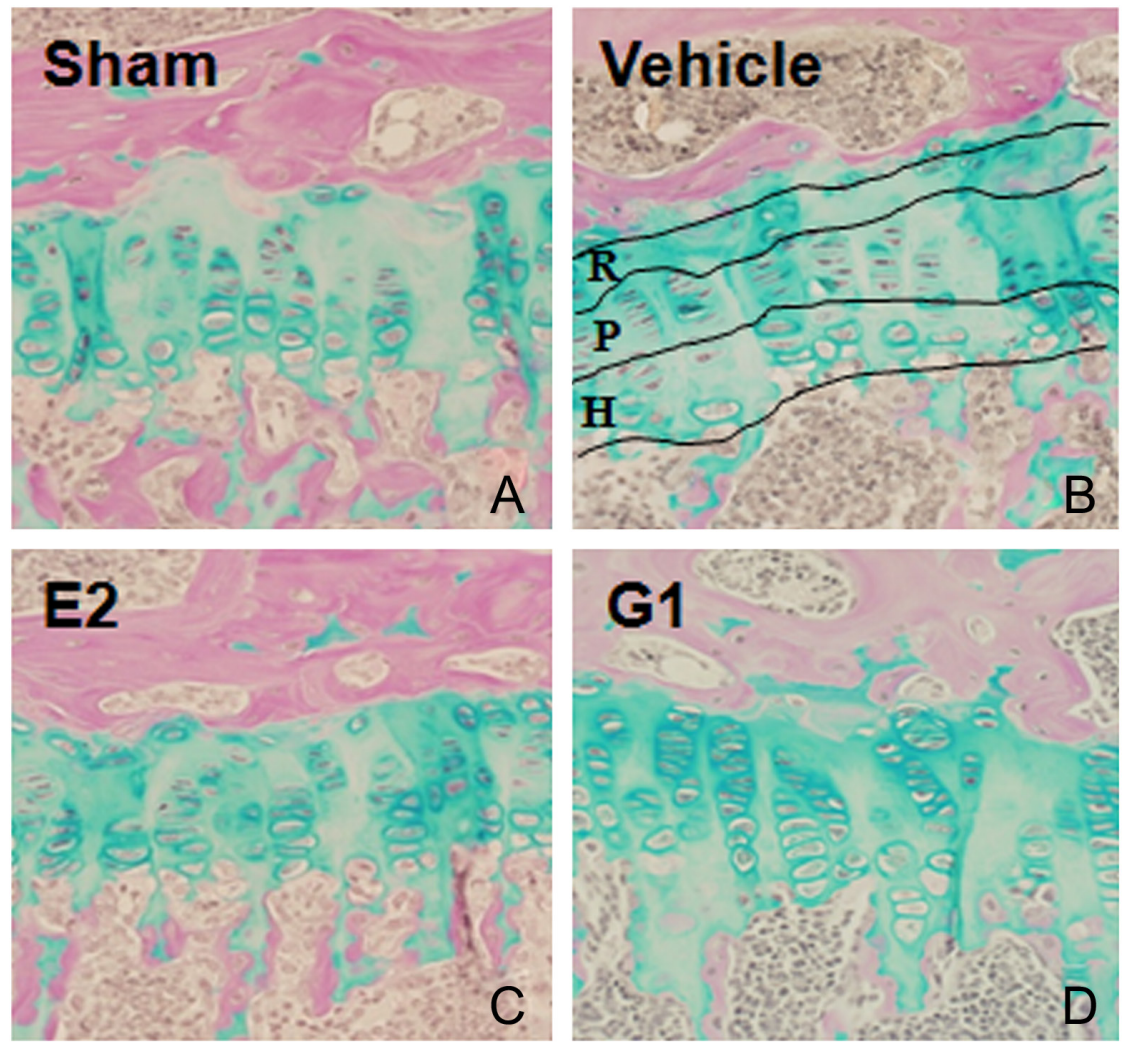

Figure 3

Effects of E2 and G1 on tibia growth plate morphology. Alcian blue/van Gieson staining of mouse proximal tibia growth plate obtained from either sham-operated or ovariectomized mice treated with E2 $(0.04 \mathrm{mg} / \mathrm{kg} / \mathrm{day}), \mathrm{G} 1(0.2 \mathrm{mg} / \mathrm{kg} /$ day), or vehicle. $\mathrm{H}$, hypertrophic zone; $\mathrm{P}$,

proliferative zone; $R$, resting zone. Treatment groups: sham (A), vehicle (B), E2 (C), and G1 (D). Magnification: $40 \times$.

\section{Discussion}

Our data clearly show that the selective GPER1 agonist G1 did not affect growth plate cartilage or bone growth at different concentrations in ex vivo-cultured mouse metatarsal bones. Furthermore, in vivo study in OVX mice has reported that ligand activation of GPER1 by the systemic administration of G1 did not influence either
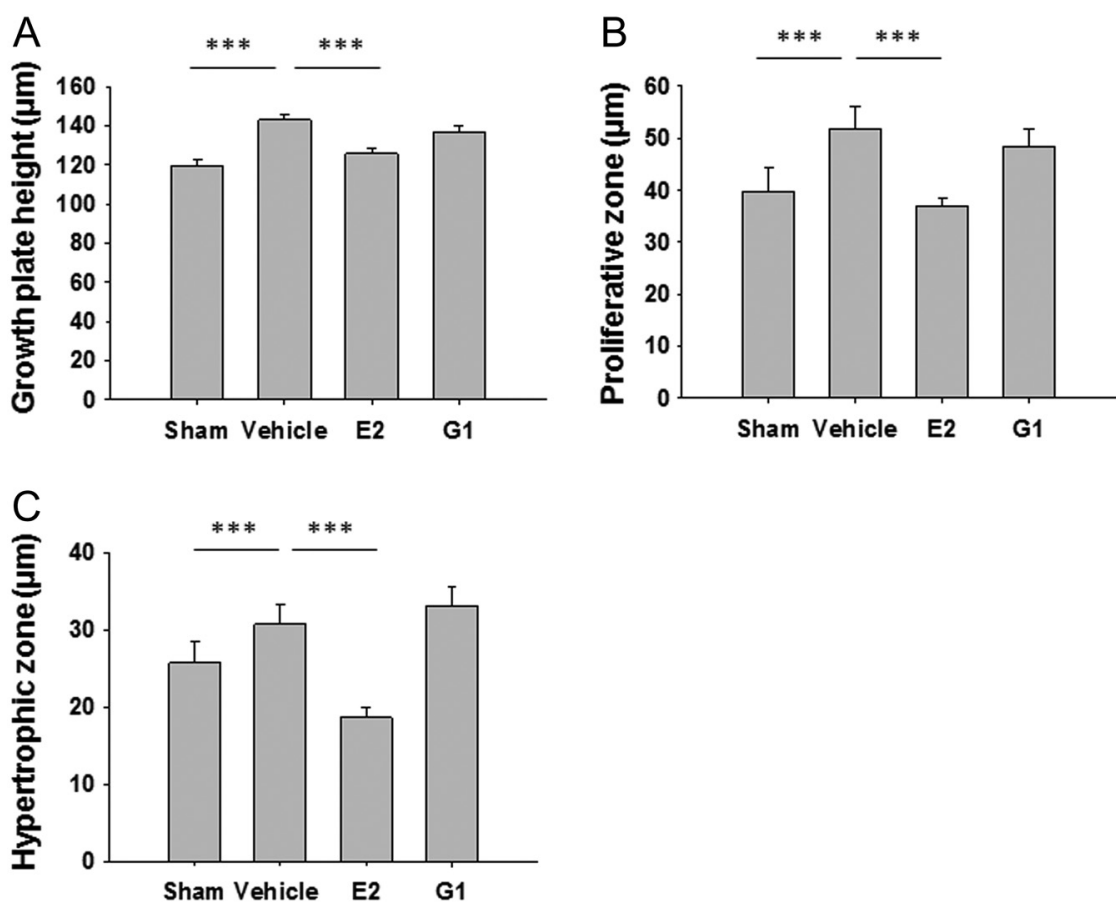

Figure 4

Effects of E2 and G1 on tibia growth plate height in different zones. The study groups included ovariectomized mice treated with E2, G1 or vehicle (DMSO) and sham-operated mice. Growth plate height (A) and height of proliferative (B) and hypertrophic (C) zones. Vehicle vs E2, vehicle vs sham: $* \star \star P<0.001(n=9-10)$. All the data are presented as means \pm S.E.M., and the differences were calculated by one-way ANOVA.

(c) 2019 The authors Published by Bioscientifica Ltd
This work is licensed under a Creative Commons Attribution-NonCommercial-NoDerivatives 4.0 delnternationab ticense ifica . com at 04/26/2023 01:56:31PM 


\section{Figure 5}

Effects of E2 and G1 on proliferation and apoptosis in tibia growth plate chondrocytes. The effects on proliferation and apoptosis were analyzed by PCNA staining (A) and TUNEL assay (B). Vehicle vs E2, vehicle vs sham: $* * * P<0.001$. No significant difference was seen between vehicle and G1 $(n=9-10)$. All the data are presented as means \pm s.E.M., and the differences were calculated by one-way ANOVA. tibia or femur growth as well as growth plate height, chondrocyte proliferation or apoptosis. In contrast, E2 suppressed both tibia and femur growth in OVX mice.

Despite the observed expression of GPER1 in mouse and human growth plate chondrocytes $(8,11)$ and bone elongation in the Gper $1^{-/}$mice (16), the therapeutic potential for GPER1 agonists has not yet been investigated. To address this gap of knowledge, we chose a well-established experimental model of ex vivo-cultured postnatal mouse metatarsal bones to study local effects on the bone growth. By testing different G1 concentrations, we found that G1 had no direct effects on metatarsal bone growth compared to control. To investigate if GPER1 stimulation influences bone growth through systemic actions, OVX mice were treated with G1. Similarly to the ex vivo results, G1 treatment did not affect tibia and femur growth in vivo. Applied as a positive control, E2 treatment suppressed bone growth and growth plate height as expected.

Our initial hypothesis that the GPER1 agonist may affect bone growth was based on earlier reported correlation between the expression of GPER1 in the growth plate and pubertal stage in children (8) as well as suppressive effects of high doses of E2 on bone growth in WT, but not in Gper $1^{-/-}$mice (15). Other studies have shown that GPER1 may regulate E2-mediated activation of transcription (21, 22) and insulin release in female mice (23). Furthermore, earlier in vitro studies have demonstrated that E2 may suppress chondrogenic differentiation of mesenchymal stem cells via GPER1 (24). Nevertheless, our present data showed that the GPER1 agonist G1 did not influence chondrocyte proliferation when applied locally to the ex vivo-cultured metatarsal bones.

Earlier published data on the expression and effects of GPER1 in different organs suggested systemic functions of ligand-activated GPER1 $(5,25)$. To evaluate potential systemic ligand-mediated actions of GPER1 on bone growth, we applied an experimental model of OVX female mice since the removal of endogenous E2 helps to identify G1-mediated effects. Our present in vivo study allowed us to conclude that systemic G1-mediated stimulation of GPER1 does not influence the growth of long bones. Furthermore, in vivo G1 treatment did not affect the heights of the growth plate or the proliferative or hypertrophic zones. A minor elongation of the hypertrophic zone was observed in the G1-treated group when compared to vehicle, although this difference was not significant. Therefore, we do not expect that G1 would affect the terminal chondrocyte differentiation in the growth plate. Moreover, systemic G1 treatment did not influence chondrocyte proliferation or apoptosis. Altogether, our data suggest that GPER1 is unlikely directly involved in the regulation of bone growth, despite the demonstrated high expression of GPER1 in the human and rodent growth plate $(8,10)$. Nevertheless, alterations of GPER1 expression during the course of the experiment cannot be excluded.

As G1 has been shown to inhibit the activity of nuclear ERs (26), this potential cross-reactivity should be considered when evaluating G1 effects in the growth plate where all three ERs are expressed. An earlier study indeed suggested that GPER1 might interact with the nuclear ESR1 (27). Moreover, as earlier published, high doses of E2 inhibited bone growth in WT but not in Gper $1^{-/-}$mice (15). In contrast to that study, we here used a selective GPER1 agonist G1 to specifically activate GPER1. This approach allowed us to investigate ligandmediated effects of GPER1 signaling in the growth plate. Several earlier findings have revealed the complexity of GPER1-mediated effects $(28,29,30)$. In addition to the ligand-mediated effects, GPER1 may act in a ligandindependent manner in the growth plate. An earlier study demonstrated ligand-independent stimulation of proliferation in ovarian tumor cells by GPER1 (28). Our present data cannot exclude ligand-independent effects of GPER1 in the growth plate. A similar dose of G1 has been used in several earlier animal studies, where significant systemic effects were documented $(18,19,29,30)$.

Thus, the present study did not confirm our hypothesis that ligand-activated GPER1 influences bone growth.

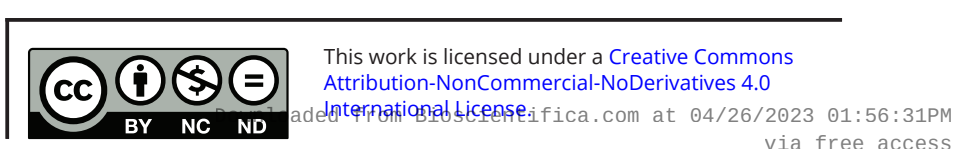


Although we performed a dose-response ex vivo study in cultured bones and tested the previously in vivo validated dose and treatment duration of G1 in mice, we cannot completely exclude that using younger mice or treating with other concentrations of G1 for longer time would lead to another conclusion.

Altogether, we conclude administration of the selective GPER1 agonist G1, either ex vivo or in vivo, did not affect bone growth or growth plate morphology. Our present data are in line with earlier published results suggesting that E2 primarily modulates bone growth via ESR1.

\section{Declaration of interest}

The authors declare that there is no conflict of interest that could be perceived as prejudicing the impartiality of the research reported.

\section{Funding}

This study was supported by Stockholm City Council (grant number 20161376), Swedish Research Council (grant number 2015-02406), Russian Science Foundation (grant number 19-15-00241), Pfizer Inc. (grant number WI177782) and a grant from Karolinska Institutet (grant number 2009Fobi0644).

\section{References}

1 Borjesson AE, Lagerquist MK, Windahl SH \& Ohlsson C. The role of estrogen receptor alpha in the regulation of bone and growth plate cartilage. Cellular and Molecular Life Sciences 201370 4023-4037. (https://doi.org/10.1007/s00018-013-1317-1)

2 Schwartz N, Verma A, Bivens CB, Schwartz Z \& Boyan BD. Rapid steroid hormone actions via membrane receptors. Biochimica et Biophysica Acta 20161863 2289-2298. (https://doi.org/10.1016/j. bbamcr.2016.06.004)

3 Kvingedal AM \& Smeland EB. A novel putative G-protein-coupled receptor expressed in lung, heart and lymphoid tissue. FEBS Letters 1997407 59-62. (https://doi.org/10.1016/s0014-5793(97)00278-0)

4 Barton M. Not lost in translation: emerging clinical importance of the G protein-coupled estrogen receptor GPER. Steroids 2016111 37-45. (https://doi.org/10.1016/j.steroids.2016.02.016)

5 Prossnitz ER \& Maggiolini M. Mechanisms of estrogen signaling and gene expression via GPR30. Molecular and Cellular Endocrinology 2009 308 32-38. (https://doi.org/10.1016/j.mce.2009.03.026)

6 Filardo EJ \& Thomas P. Minireview: G protein-coupled estrogen receptor-1, GPER-1: its mechanism of action and role in female reproductive cancer, renal and vascular physiology. Endocrinology 2012153 2953-2962. (https://doi.org/10.1210/en.2012-1061)

7 Zavatti M, Guida M, Maraldi T, Beretti F, Bertoni L, La Sala GB \& De Pol A. Estrogen receptor signaling in the ferutinin-induced osteoblastic differentiation of human amniotic fluid stem cells. Life Sciences 2016164 15-22. (https://doi.org/10.1016/j.lfs.2016.09.005)

8 Chagin AS \& Savendahl L. GPR30 estrogen receptor expression in the growth plate declines as puberty progresses. Journal of Clinical Endocrinology and Metabolism 200792 4873-4877. (https://doi. org/10.1210/jc.2007-0814)

9 Heino TJ, Chagin AS \& Savendahl L. The novel estrogen receptor G-protein-coupled receptor 30 is expressed in human bone. Journal of Endocrinology 2008197 R1-R6. (https://doi.org/10.1677/JOE-070629)

10 Li XF, Wang SJ, Jiang LS \& Dai LY. Gender- and region-specific variations of estrogen receptor alpha and beta expression in the growth plate of spine and limb during development and adulthood. Histochemistry and Cell Biology 2012137 79-95. (https://doi. org/10.1007/s00418-011-0877-0)

11 Fan DX, Yang XH, Li YN \& Guo L. 17Beta-estradiol on the expression of G-protein coupled estrogen receptor (GPER/GPR30) mitophagy, and the PI3K/Akt signaling pathway in ATDC5 chondrocytes in vitro. Medical Science Monitor 201824 1936-1947. (https://doi. org/10.12659/msm.909365)

12 Revankar CM, Cimino DF, Sklar LA, Arterburn JB \& Prossnitz ER. A transmembrane intracellular estrogen receptor mediates rapid cell signaling. Science 2005307 1625-1630. (https://doi.org/10.1126/ science.1106943)

13 Maggiolini M, Vivacqua A, Fasanella G, Recchia AG, Sisci D, Pezzi V, Montanaro D, Musti AM, Picard D \& Ando S. The G protein-coupled receptor GPR30 mediates c-fos up-regulation by 17beta-estradiol and phytoestrogens in breast cancer cells. Journal of Biological Chemistry 2004279 27008-27016. (https://doi.org/10.1074/jbc.M403588200)

14 Vivacqua A, Bonofiglio D, Recchia AG, Musti AM, Picard D, Ando S \& Maggiolini M. The G protein-coupled receptor GPR30 mediates the proliferative effects induced by 17 beta-estradiol and hydroxytamoxifen in endometrial cancer cells. Molecular Endocrinology 200620 631-646. (https://doi.org/10.1210/me.20050280)

15 Windahl SH, Andersson N, Chagin AS, Martensson UE, Carlsten H, Olde B, Swanson C, Moverare-Skrtic S, Savendahl L, Lagerquist MK, et al. The role of the G protein-coupled receptor GPR30 in the effects of estrogen in ovariectomized mice. American Journal of Physiology: Endocrinology and Metabolism 2009296 E490-E496. (https://doi. org/10.1152/ajpendo.90691.2008)

16 Ford J, Hajibeigi A, Long M, Hahner L, Gore C, Hsieh JT, Clegg D, Zerwekh J \& Oz OK. GPR30 deficiency causes increased bone mass, mineralization, and growth plate proliferative activity in male mice. Journal of Bone and Mineral Research 201126 298-307. (https://doi. org/10.1002/jbmr.209)

17 Chagin AS, Karimian E, Sundstrom K, Eriksson E \& Savendahl L. Catch-up growth after dexamethasone withdrawal occurs in cultured postnatal rat metatarsal bones. Journal of Endocrinology 2010204 21-29. (https://doi.org/10.1677/JOE-09-0307)

18 Bourque M, Morissette M, Cote M, Soulet D \& Di Paolo T. Implication of GPER1 in neuroprotection in a mouse model of Parkinson's disease. Neurobiology of Aging 201334 887-901. (https:// doi.org/10.1016/j.neurobiolaging.2012.05.022)

19 Engdahl C, Jochems C, Windahl SH, Borjesson AE, Ohlsson C, Carlsten $\mathrm{H}$ \& Lagerquist MK. Amelioration of collagen-induced arthritis and immune-associated bone loss through signaling via estrogen receptor alpha, and not estrogen receptor beta or $\mathrm{G}$ proteincoupled receptor 30. Arthritis and Rheumatism 201062 524-533. (https://doi.org/10.1002/art.25055)

20 Iravani M, Lagerquist M, Ohlsson C \& Savendahl L. Regulation of bone growth via ligand-specific activation of estrogen receptor alpha. Journal of Endocrinology 2017232 403-410. (https://doi.org/10.1530/ JOE-16-0263)

21 Prossnitz ER, Arterburn JB, Smith HO, Oprea TI, Sklar LA \& Hathaway HJ. Estrogen signaling through the transmembrane G protein-coupled receptor GPR30. Annual Review of Physiology 200870 165-190. (https://doi.org/10.1146/annurev. physiol.70.113006.100518)

22 Prossnitz ER, Sklar LA, Oprea TI \& Arterburn JB. GPR30: a novel therapeutic target in estrogen-related disease. Trends in Pharmacological Sciences 200829 116-123. (https://doi.org/10.1016/j. tips.2008.01.001) https://ec.bioscientifica.com https://doi.org/10.1530/EC-19-0274 (c) 2019 The authors Published by Bioscientifica Ltd
This work is licensed under a Creative Commons Attribution-NonCommercial-NoDerivatives 4.0 Internationad ticense ifica.com at 04/26/2023 01:56:31PM 
23 Martensson UE, Salehi SA, Windahl S, Gomez MF, Sward K, Daszkiewicz-Nilsson J, Wendt A, Andersson N, Hellstrand P, Grande PO, et al. Deletion of the G protein-coupled receptor 30 impairs glucose tolerance, reduces bone growth, increases blood pressure, and eliminates estradiol-stimulated insulin release in female mice. Endocrinology 2009150 687-698. (https://doi.org/10.1210/ en.2008-0623)

24 Jenei-Lanzl Z, Straub RH, Dienstknecht T, Huber M, Hager M, Grassel S, Kujat R, Angele MK, Nerlich M \& Angele P. Estradiol inhibits chondrogenic differentiation of mesenchymal stem cells via nonclassic signaling. Arthritis and Rheumatism 201062 1088-1096. (https://doi.org/10.1002/art.27328)

25 Mizukami Y. In vivo functions of GPR30/GPER-1, a membrane receptor for estrogen: from discovery to functions in vivo. Endocrine Journal 201057 101-107. (https://doi.org/10.1507/endocrj.K09E-332)

26 Smith LC, Ralston-Hooper KJ, Ferguson PL \& Sabo-Attwood T. The $\mathrm{G}$ protein-coupled estrogen receptor agonist G-1 inhibits nuclear estrogen receptor activity and stimulates novel phosphoproteomic signatures. Toxicological Sciences 2016151 434-446. (https://doi. org/10.1093/toxsci/kfw057)
27 Romano SN \& Gorelick DA. Crosstalk between nuclear and G protein-coupled estrogen receptors. General and Comparative Endocrinology 2018261 190-197. (https://doi.org/10.1016/j. ygcen.2017.04.013)

28 Yan Y, Jiang X, Zhao Y, Wen H \& Liu G. Role of GPER on proliferation, migration and invasion in ligand-independent manner in human ovarian cancer cell line SKOV3. Cell Biochemistry and Function 201533 552-559. (https://doi. org/10.1002/cbf.3154)

29 Lebesgue D, Reyna-Neyra A, Huang X \& Etgen AM. GPR30 differentially regulates short latency responses of luteinising hormone and prolactin secretion to oestradiol. Journal of Neuroendocrinology 200921 743-752. (https://doi.org/10.1111/j.13652826.2009.01893.x)

30 Dominguez-Ordonez R, Garcia-Juarez M, Lima-Hernandez FJ, Gomora-Arrati P, Dominguez-Salazar E, Blaustein JD, Etgen AM \& Gonzalez-Flores O. Lordosis facilitated by GPER-1 receptor activation involves GnRH-1, progestin and estrogen receptors in estrogenprimed rats. Hormones and Behavior 201898 77-87. (https://doi. org/10.1016/j.yhbeh.2017.12.005)

Received in final form 6 August 2019

Accepted 20 August 2019

Accepted Preprint published online 21 August 2019 (c) 2019 The authors Published by Bioscientifica Ltd
This work is licensed under a Creative Commons Attribution-NonCommercial-NoDerivatives 4.0 Internationab bicense.ifica . com at 04/26/2023 01:56:31PM 